\title{
Effectiveness Degree on Orientation for Beginning/Newly Transferred Teachers in Ondo State Nigeria
}

\author{
Jolly Dojo Kukuru \\ Department of Social Science Education \\ Adekunle Ajasin University, Akungba Akoko, Ondo State, Nigeria
}

\begin{abstract}
Orientation is used in this article as training or information that beginning/newly transferred teachers receive before settling down as service teachers. Obviously, the essence is to get such teachers equipped with basic practice situations of the school. This article focuses on effectiveness degree on orientation for beginning/newly transferred teachers in ondo state, Nigeria. It is the product of a survey. All supervisors of secondary schools in ondo state Nigeria formed the population. Twelve (12) out of the eighteen Local Government Area supervisors and the central supervisor (1) in the ministry of education formed the sample. A Likert type of questionnaire as instrument was used to obtain required data. Its validity and reliability values are 0.85 and 0.96 as " $r$ " respectively. Three hypotheses were postulated and tested after obtaining required data. Findings showed that effectiveness degree on orientation for beginning Inewly transferred teachers in Ondo State Nigeria is generally high but a number of specific areas require improvement. Suggestions are made involving supervisors, principals, heads of department, as well as other experienced teachers, on measures to take toward realizing required improvements.
\end{abstract}

\section{Introduction}

Orientation for beginning/newly transferred teachers is identified as a component of professional development [1]. Several other authors directly or indirectly agree including [2], [3], [4], [5], [6], [7], and [8]. [2] concisely noted a number of points on the need for orientation for new educators:

- College and university programmes cannot provide required extensive range of learning experiences to become effective public school educators. New teachers have to contend with such issues as classroom management, instruction, curriculum, school culture and operations, test preparation and administration, government standards,

parent-teacher relations as well as teacher-teacher inter-relationships. If new teachers are not provided with orientation, there is tendency for them to develop counter-productive behaviours on these issues.

- Orientation programmes assist districts in retaining new teachers which later makes such teachers effective educators.

- Orientation programmes are required in many governments for teachers to earn professional license.

- There is research evidence that new teachers that received intensive mentoring had significant effect on student performance just after two years.

- New principals as well as assistant principals benefit from on-going professional learning when they assume new roles: need to know district, state, and federal policies, laws, and procedures, requires considerable time for study and application.

These points portray orientation as a major component of professional development.

Certain issues on professional development generally, may be highlighted. One of them is that professional development had been presented by experts as a major avenue for improving curriculum and renewing secondary schools [9]; [1]; [2]; [10]; [6]; and [8]). Moreover, the focus of professional development is improved student learning/performance through enhanced teacher learning/performance. The process is to first improve teacher or educator so that the teacher/educator would be competent enough to improve learning/performance of students. A point on methodology is that, methods should be perceived as secondary; rather, what to learn should be underscored. While some authors such as [11], [4], [12], put it mildly, [3] was loud on the issue with the following assertion: "no activity or process whether facilitated by others or self-directed, was consistently associated with improved student success. 
A germane point is that professional development should be on-going. Hardly is there any author that contradicts this position directly or indirectly sequel to its reality such that even when it is not directly mentioned, it is embedded. For example, [13] observed that teachers successfully changed their practice toward reform-aligned instructional goals in schools which demonstrated high growth in providing reform-complied professional development. Two issues suggest the need for on-going research in this statement. First is the basis which is reform-aligned instructional goals and second is that schools which demonstrated high growth in improving reformcomplied professional development programmes succeeded in changing the practices of teachers. Another example is that of [14]; the authors suggested that professional development programmes should build on teachers' cognitions and practices. In a dynamic intellectual world, to build on cognitions and practices obviously require an on-going process.

Proximately, orientation is distinct on the ground that it is mainly meant for beginning/newly transferred teachers/educators. Thus, it is necessary by concept, for teachers that graduate, virtually every year and other teachers transferred. While transfer may not affect every teacher annually, some teachers are usually transferred each year. Consequently, such newly transferred teachers and graduates of each year, require orientation. Tersely, orientation for beginning/newly transferred teachers/educators as a component of professional development can be an annual affair fundamentally and subsequent years' programmes are expected to improve on previous programmes.

[15] was an article on: stage of professional development toward reforming secondary schools in Ondo State, Nigeria. The article showed that prior to the research which produced it, three empirical researches only, namely, those of [16], [17], and [18], were readily available in the whole of Nigeria and none of them was conducted in Ondo State. Accordingly, as many as possible empirical researches were required on professional development in Ondo State and Nigeria generally. Moreover, the overall finding of [15] was that stage of professional development in secondary schools in Ondo State, Nigeria was high. It was suggested that several empirical researches were required for a clearer picture. Such empirical researches should focus on vital features of professional development, orientation for beginning and newly transferred teachers, problem solving devices, and service teachers' relations with student teachers.

\section{Statement of the problem}

The fore-going brief introduction portrays that professional development is germane to enhance performances of teachers and in turn improve students' learning. Moreover, professional development should be on-going. On this premise, hardly can researches on it be too many in a season, anywhere in the world. Furthermore, orientation for beginning/newly transferred teachers is a major component of professional development. Proximately, this component of professional development had been identified as one whose empirical research results were required to shed more light on stage of professional development in a particular school environment. Consequently, the problem of this research is: effectiveness degree on orientation for beginning/newly transferred teachers in Ondo State, Nigeria.

\section{Purpose of research}

The purpose of this research was to:

1. Verify degree to which orientation programme for beginning/newly transferred teachers is considered important in Ondo State, Nigeria.

2. Determine degree of effectiveness on major features of orientation programme for beginning/newly transferred teachers in Ondo state, Nigeria.

3. Ascertain magnitude of involvement of all beginning/newly transferred teachers by principals in the whole programmes of their schools in Ondo State Nigeria.

\section{Research questions}

Answers will be sought for the following questions in this research.

1. To what degree is orientation programme considered important for beginning/newlytransferred teachers in Ondo State, Nigeria?

2. To what degree is the effectiveness on major features of orientation programme for beginning/newly transferred teachers in Ondo State, Nigeria?

3. To what magnitude do Principals involve all beginning/newly transferred teachers in the whole programmes of their schools in Ondo State, Nigeria? 


\section{Research hypotheses}

The following hypotheses will be tested in this research.

1. Degree of importance for orientation programme for beginning/newly transferred teachers is low in Ondo State, Nigeria.

2. Degree of effectiveness on major features of orientation programme for beginning/newly transferred teachers is low, in Ondo State, Nigeria.

3. Magnitude of involvement of all beginning/newly transferred teachers by Principals in the whole programmes of their schools is low in Ondo State, Nigeria.

\section{Significance of the research}

This research is significant because it will increase empirical researches on professional development in Nigeria and the globe generally. Secondly, its results will shed more light on stage of professional development in Ondo State with particular respect to orientation for beginning/newly transferred teachers. Finally, it will provide empirical data for researchers, curriculum development specialists, teacher trainers, supervisors of schools, principals, and teachers.

\section{Research Methodology}

The design for this research is a survey. A Likert type of questionnaire was employed as instrument in obtaining required data on a current societal problem. All supervisors of secondary schools in Ondo State Nigeria, formed the population of this research. The State has a total of eighteen Zonal/Area Education Officers, one Officer being in charge of each Zonal/Area Education Office in each Local Government Area. On the ground that this research is a follow up from [15], it was considered necessary to involve the same secondary school supervisors as respondents. Twelve (12) out of the eighteen Zonal/Area Education Officers as well as the over-all supervisor based in the Ministry of Education, formed the sample. The total sample was then thirteen (13) which quite represented the state: $66.7 \%$ for the Zonal/Area supervisors, $72.2 \%$ generally, and $100 \%$ for the Ministry of Education.

Purposive sampling process was employed in order to involve four out of six Local Government Areas from each of the three Senatorial Districts in the State.
The Likert type of questionnaire was developed by the researcher. It contains eighteen items which covered three units, namely: degree of importance attached to orientation (items 1\&2), degree of effectiveness on major features of orientation (items 3-17), and magnitude of involvement of new teachers by Principals in all programmes of their schools (item 18) (Please see Table 1a below). The items were informed by authors including [1], [2], [13], [14], and [7].

Test and measurement as well as curriculum specialists effected the face and content validity processes. Convergence test [19] was conducted for the construct validity. The instrument was administered to four Principals and eight teachers in two secondary schools in Central Senatorial District of Ondo State. The same instrument was also administered to another group of four Principals and eight teachers, in two other secondary schools, very distant from the other two: in Southern Senatorial District of the State. Simple percentage results of the two separate administrations of the instrument, were: $76.7 \%$ against $23.3 \%$ and $70.0 \%$ against $30.0 \%$ for Central Senatorial and Southern Senatorial Districts, respectively. Although it was apparent enough that the result indicated convergence, conclusive analysis through Pearson Product Moment Correlation coefficient yielded " $r$ " as 0.85 .

Reliability of the instrument was verified through test re-test process. The questionnaire was administered to twelve (12) educators: four Principals and eight (8) teachers in Central Senatorial District of Ondo State twice, at an interval of two weeks. Simple percentage results obtained were: $76.7 \%$ against $23.3 \%$ and $78.3 \%$ against $21.7 \%$ for first and second tests respectively. While it was obvious enough that the result suggested that the instrument was reliable, conclusive analysis was affected by Pearson Product Moment Correlation and a coefficient " $r$ " 0.96 was obtained.

A letter of introduction of the researcher was issued by his Dean, Faculty of Education, Adekunle Ajasin University, Akungba Akoko, Ondo State, Nigeria, to enable him formally approach respondents. On the basis that the sample is small in number, although representing the whole State, it was necessary to collect each copy from each Zonal/Area Education in all the three Senatorial Districts of the State; all copies were finally collected.

Obtained data were analysed using frequencies, percentages, and Chi-Square statistics because the data obtained did not require further probing. 
Table 1a: The Instrument that was administered

\begin{tabular}{|c|c|c|c|c|}
\hline Items and their groups & $\begin{array}{l}\text { Strongly } \\
\text { Agree }\end{array}$ & Agree & Disagree & $\begin{array}{l}\text { Strongly } \\
\text { Disagree }\end{array}$ \\
\hline \multicolumn{5}{|l|}{$\begin{array}{l}\text { I. Degree of importance attached to } \\
\text { orientation }\end{array}$} \\
\hline \multicolumn{5}{|l|}{$\begin{array}{l}\text { 1. Orientation of beginning/newly } \\
\text { transferred teachers is vital. }\end{array}$} \\
\hline \multicolumn{5}{|l|}{$\begin{array}{l}\text { 2. Sufficient duration is given to orientation } \\
\text { programme that is conducted for beginning } \\
\text { teachers. }\end{array}$} \\
\hline \multicolumn{5}{|l|}{$\begin{array}{l}\text { II. Effectiveness degree on features of } \\
\text { orientation }\end{array}$} \\
\hline \multicolumn{5}{|l|}{$\begin{array}{l}\text { 3. In the orientation programme for } \\
\text { beginning teachers, their problems/concerns } \\
\text { are shared openly. }\end{array}$} \\
\hline \multicolumn{5}{|l|}{$\begin{array}{l}\text { 4. Appropriate support is provided for the } \\
\text { problem/concerns of beginning teachers } \\
\text { through the orientation programme. }\end{array}$} \\
\hline \multicolumn{5}{|l|}{$\begin{array}{l}\text { 5. Required material resources are supplied } \\
\text { to beginning teachers through the } \\
\text { orientation programme. }\end{array}$} \\
\hline \multicolumn{5}{|l|}{$\begin{array}{l}\text { 6. Special supervisory assistance is } \\
\text { provided for beginning teachers to help } \\
\text { them in their transition from pre-service } \\
\text { education to professional teaching. }\end{array}$} \\
\hline \multicolumn{5}{|l|}{$\begin{array}{l}\text { 7. Special supervisory assistance is } \\
\text { provided for beginning teachers to ensure } \\
\text { their professional growth through various } \\
\text { measures: appropriate assignments/adequate } \\
\text { resource materials/measures toward } \\
\text { preventing teacher isolation. }\end{array}$} \\
\hline \multicolumn{5}{|l|}{$\begin{array}{l}\text { 8. Beginning teachers are not assigned to } \\
\text { courses that are rejected by experienced } \\
\text { teachers. }\end{array}$} \\
\hline \multicolumn{5}{|l|}{$\begin{array}{l}\text { 9. Beginning teachers are not assigned to } \\
\text { students that are rejected by experienced } \\
\text { teachers. }\end{array}$} \\
\hline \multicolumn{5}{|l|}{$\begin{array}{l}\text { 10. Beginning teachers are not assigned to } \\
\text { facilities that are regarded as less desirable } \\
\text { by experienced teachers. }\end{array}$} \\
\hline \multicolumn{5}{|l|}{$\begin{array}{l}\text { 11. The support system for new teachers } \\
\text { encourages them to seek assistance on } \\
\text { problems that they encounter. }\end{array}$} \\
\hline \multicolumn{5}{|l|}{$\begin{array}{l}\text { 12. Assistance sought by new teachers is } \\
\text { readily provided by the school. }\end{array}$} \\
\hline \multicolumn{5}{|l|}{$\begin{array}{l}\text { 13. New teachers participate in the selection } \\
\text { of curricular materials that they will use in } \\
\text { their classes. }\end{array}$} \\
\hline \multicolumn{5}{|l|}{$\begin{array}{l}\text { 14. The working climate provides } \\
\text { opportunities for beginning/newly } \\
\text { transferred teachers to express their ideas } \\
\text { toward improving the educational } \\
\text { programme. }\end{array}$} \\
\hline $\begin{array}{l}\text { 15. The working climate provides for ideas } \\
\text { of beginning/newly transferred teachers to } \\
\text { be valued by the entire professional staff. }\end{array}$ & & & & \\
\hline
\end{tabular}




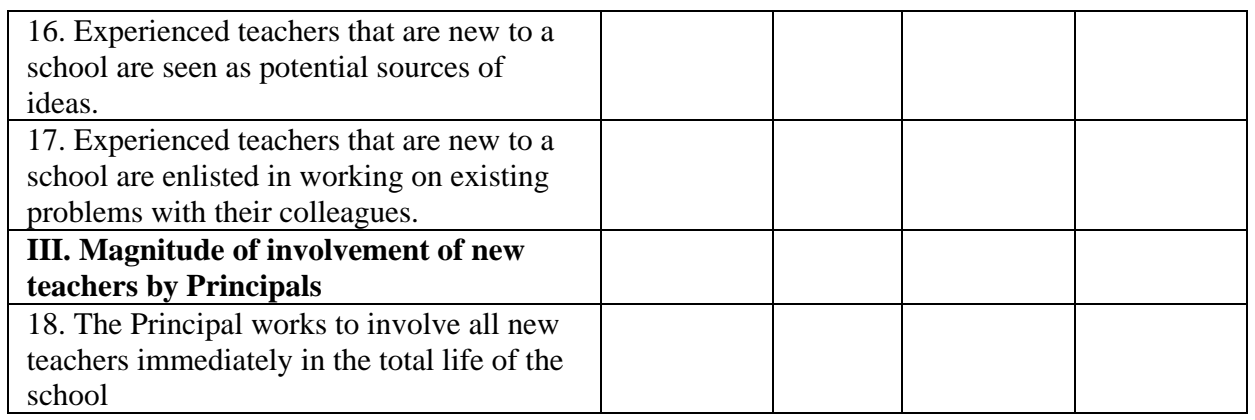

\section{Results}

Results obtained from analysis of data collected are presented in Tables below.

\section{Research Questions' Feedback}

The questions which guided this research are hereby answered.

Research Question 1: To what degree is orientation programme considered important for beginning/newly transferred teachers in Ondo State, Nigeria?

The summary result for this question is shown below item 2 in Table $1 \mathrm{~b}$. The average percentage of strongly agree plus agree is 80.77 ; it indicates that orientation programme is considered quite important by the respondents.

Research Question 2: To what degree is the effectiveness on the major features of orientation programme for beginning/newly transferred teachers in Ondo State, Nigeria?

Summary result on the fifteen items (3-17) is presented on the row after item 17 and the average for strongly agree plus agree is $67.69 \%$. This figure is high enough and it implies that orientation programme for beginning/newly transferred teachers is generally effectve.

Research Question 3: To what magnitude do Principals involve all beginning/newly transferred

teachers in the whole programmes of their schools in Ondo State, Nigeria?

This conclusive/evaluative question is answered by the figures on item 18 on Table $1 \mathrm{~b}$. The strongly agree plus agree figures show $76.92 \%$ which indicates that the Principals considerably involved all beginning and newly transferred teachers in the whole programmes of their school.

\section{Testing of hypotheses}

The three hypotheses that were generated for this research are hereby tested.

Hypothesis 1 states that: Degree of importance for orientation programme for beginning and newly transferred teachers in Ondo State, Nigeria is low. Data provided in Table 2 enables testing of this hypothesis. The table presents summary responses on combined agree and combined disagree and the ChiSquare (X2) value for their comparison is 38.440 at 0.000 levels of significance. This result displays that responses on combined agree are significantly different from responses on combined disagree which connotes that degree of importance for orientation programme for beginning/newly transferred teachers in Ondo State Nigeria is high. Consequently, hypothesis 1 is rejected.

Hypothesis 2 states that: Degree of effectiveness on major features of orientation programme for beginning/newly transferred teachers in Ondo State Nigeria is low. Data presented in Table 3, provides the basis for testing this hypothesis. Chi - Square (X2) comparison for the combined agree and combined disagree gives the value of 12.960 at 0.000 levels of significance. This result indicates that responses on combined agree are significantly different from combined disagree and the implication is that degree of effectiveness on major features of orientation programme for beginning/ newly transferred teachers in Ondo State Nigeria is high. Accordingly, hypothesis 2 is rejected.

Hypothesis 3 states that: Magnitude of involvement of all beginning/newly transferred teachers by Principals in the whole programmes of their schools in Ondo State, Nigeria is low. Information, by figures, provided in Table 4, enables testing of this hypothesis. The figures display Chi- Square (X2) comparison between combined agree and combined disagree which shows the value 29.160 at 0.000 levels of significance. This result portrays that responses on combined agree are 
Table 1b: Frequencies and percentage of all responses to the questionnaire administered, and their summaries

\begin{tabular}{|c|c|c|c|c|c|c|c|c|c|}
\hline $\begin{array}{l}\text { Serial } \\
\text { Number }\end{array}$ & Unit & $\begin{array}{l}\% \\
\text { SA +A }\end{array}$ & $\mathrm{SA}+\mathrm{A}$ & SA & A & $\mathrm{D}$ & SD & $\mathrm{D}+\mathrm{SD}$ & $\begin{array}{l}\% \\
\mathrm{D}+\mathrm{SD}\end{array}$ \\
\hline \multirow[t]{4}{*}{ I } & $\begin{array}{l}\text { Degree of } \\
\text { importance } \\
\text { attached to } \\
\text { orientation }\end{array}$ & & & & & & & & \\
\hline & 1 & 84.62 & 11 & 9 & 2 & 0 & 2 & 2 & 15.38 \\
\hline & 2 & 76.92 & 10 & 4 & 6 & 2 & $\overline{1}$ & 3 & 23.08 \\
\hline & Summary & 80.77 & 10.5 & 6.5 & 4 & 1 & 1.5 & 2.5 & 19.23 \\
\hline \multirow[t]{17}{*}{ II } & $\begin{array}{l}\text { Effectiveness } \\
\text { degree on } \\
\text { features of } \\
\text { orientation }\end{array}$ & & & & & & & & \\
\hline & 3 & 53.85 & 7 & 1 & 6 & 4 & 2 & 6 & 46.15 \\
\hline & 4 & 76.92 & 10 & 1 & 9 & 2 & 1 & 3 & 23.08 \\
\hline & 5 & 69.23 & 9 & 3 & 6 & 2 & 2 & 4 & 30.77 \\
\hline & 6 & 76.92 & 10 & 2 & 8 & 3 & 0 & 3 & 23.08 \\
\hline & 7 & 61.54 & 8 & 2 & 6 & 4 & 1 & 5 & 38.46 \\
\hline & 8 & 46.15 & 6 & 2 & 4 & 4 & 3 & 7 & 53.85 \\
\hline & 9 & 53.85 & 7 & 2 & 5 & 3 & 3 & 6 & 46.15 \\
\hline & 10 & 53.85 & 7 & 2 & 5 & 4 & 2 & 6 & 46.15 \\
\hline & 11 & 84.62 & 11 & 2 & 9 & 1 & 1 & 2 & 15.38 \\
\hline & 12 & 46.15 & 6 & 2 & 4 & 5 & 2 & 7 & 53.85 \\
\hline & 13 & 53.85 & 7 & 2 & 6 & 4 & 2 & 6 & 46.15 \\
\hline & 14 & 69.23 & 9 & 4 & 5 & 4 & 0 & 4 & 30.77 \\
\hline & 15 & 84.62 & 11 & 0 & 11 & 2 & 0 & 2 & 15.38 \\
\hline & 16 & 92.31 & 12 & 5 & 7 & 0 & 1 & 1 & 7.69 \\
\hline & 17 & 92.31 & 12 & 6 & 6 & 0 & 1 & 1 & 7.69 \\
\hline & Summary & 67.69 & 8.8 & 2.4 & 6.7 & 2.8 & 1.4 & 4.2 & 32.31 \\
\hline \multirow[t]{3}{*}{ III } & $\begin{array}{l}\text { Magnitude of } \\
\text { involvement of } \\
\text { new teachers } \\
\text { by Principals }\end{array}$ & & & & & & & & \\
\hline & 18 & 76.92 & 10 & 6 & 4 & 3 & 0 & 3 & 23.08 \\
\hline & Summary & 76.92 & 10 & 6 & 4 & 3 & 0 & 3 & 23.08 \\
\hline
\end{tabular}


Table 2. Result of Chi-Square $\left(\mathrm{X}^{2}\right)$ comparison on summary scores on vitality of orientation and duration

\begin{tabular}{|l|l|l|l|l|l|l|l|l|l|}
\hline Unit & $\begin{array}{l}\text { Average } \\
\text { Score of } \\
\text { Strongly } \\
\text { Agree } \\
\text { Plus } \\
\text { Agree }\end{array}$ & $\begin{array}{l}\text { Average } \\
\text { Score of } \\
\text { Strongly } \\
\text { Disagree } \\
\text { Plus } \\
\text { Disagree }\end{array}$ & $\begin{array}{l}\text { Percentage } \\
\text { of Strongly } \\
\text { Agree Plus } \\
\text { Agree }\end{array}$ & $\begin{array}{l}\text { Percentage } \\
\text { of } \\
\text { Strongly } \\
\text { Disagree } \\
\text { Plus } \\
\text { Disagree }\end{array}$ & $\begin{array}{l}X^{2} \\
\text { Value }\end{array}$ & $\begin{array}{l}\text { Degree } \\
\text { of } \\
\text { Freedom }\end{array}$ & $\begin{array}{l}\text { Table } \\
\text { Value }\end{array}$ & $\begin{array}{l}\text { Significance } \\
\text { Level }\end{array}$ & Remark \\
\hline $\begin{array}{l}\text { Vitality of } \\
\text { Orientation } \\
\text { Programme } \\
\text { and } \\
\text { Duration }\end{array}$ & 10.5 & 2.5 & 80.77 & 19.23 & 38.440 & 1 & 3.841 & 0.000 & \\
\hline
\end{tabular}

Table 3. Result of Chi - Square $\left(\mathrm{X}^{2}\right)$ comparison on major features of orientation programme

\begin{tabular}{|l|l|l|l|l|l|l|l|l|l|}
\hline Unit & $\begin{array}{l}\text { Average } \\
\text { score of } \\
\text { Strongly } \\
\text { Agree } \\
\text { plus } \\
\text { Agree }\end{array}$ & $\begin{array}{l}\text { Average } \\
\text { score of } \\
\text { Strongly } \\
\text { Disagree } \\
\text { plus } \\
\text { Disagree }\end{array}$ & $\begin{array}{l}\text { Percentage } \\
\text { of } \\
\text { Strongly } \\
\text { Agree plus } \\
\text { Agree }\end{array}$ & $\begin{array}{l}\text { Percentage } \\
\text { of } \\
\text { Strongly } \\
\text { Disagree } \\
\text { plus } \\
\text { Disagree }\end{array}$ & $\begin{array}{l}\mathrm{X}^{2} \\
\text { Value }\end{array}$ & $\begin{array}{l}\text { Degree } \\
\text { of } \\
\text { freedom }\end{array}$ & $\begin{array}{l}\text { Table } \\
\text { Value }\end{array}$ & $\begin{array}{l}\text { Significance } \\
\text { Level }\end{array}$ & Remark \\
\hline $\begin{array}{l}\text { Major } \begin{array}{l}\text { Features of } \\
\text { Orientation } \\
\text { programme }\end{array} \\
8.8\end{array}$ & 4.2 & 67.69 & 32.31 & 12.960 & 1 & 3.841 & 0.000 & \\
\hline
\end{tabular}

Table 4. Result of Chi - Square $\left(\mathrm{X}^{2}\right)$ comparison on degree of involvement of new teachers by Principals

\begin{tabular}{|l|l|l|l|l|l|l|l|l|l|}
\hline Unit & $\begin{array}{l}\text { Average } \\
\text { score of } \\
\text { Strongly } \\
\text { Agree } \\
\text { plus } \\
\text { Agree }\end{array}$ & $\begin{array}{l}\text { Average } \\
\text { score of } \\
\text { Strongly } \\
\text { Disagree } \\
\text { plus } \\
\text { Disagree }\end{array}$ & $\begin{array}{l}\text { Percentage } \\
\text { of Strongly } \\
\text { Agree plus } \\
\text { Agree }\end{array}$ & $\begin{array}{l}\text { Percentage } \\
\text { of Strongly } \\
\text { Disagree } \\
\text { plus } \\
\text { Disagree }\end{array}$ & $\begin{array}{l}\mathrm{X}^{2} \\
\text { Value }\end{array}$ & $\begin{array}{l}\text { Degree } \\
\text { of } \\
\text { freedom }\end{array}$ & $\begin{array}{l}\text { Table } \\
\text { Value }\end{array}$ & $\begin{array}{l}\text { Significance } \\
\text { Level } \\
\text { Significance } \\
\text { Level }\end{array}$ & Remark \\
\hline $\begin{array}{l}\text { Degree of } \\
\text { Involvement } \\
\text { of All New } \\
\text { Teachers by } \\
\text { Principals }\end{array}$ & 10 & 3 & 76.92 & 23.08 & 29.160 & 1 & 3.841 & 0.000 & Significant \\
\hline
\end{tabular}

significantly different from combined disagree which implies that magnitude of involvement of all beginning/ newly transferred teachers by Principals in the whole programmes of their schools in Ondo State Nigeria is high. Consequently, hypothesis 3 is rejected.

\section{Discussion of findings}

The first finding from this research is that degree of importance for orientation programme for beginning/newly transferred teachers in Ondo State Nigeria is high. This result supports evidence from literature ([1]; [2]; [3]; [10]; [8]; [7]; [6]) on the importance of orientation as a component of professional development. It may thus be stated that the supervisors of education who represented principals and teachers in Ondo State Nigeria were current on the issue of orientation for beginning/newly transferred teachers, as a component of professional development; they were well informed.

Second finding is that degree of effectiveness of major features of orientation programme for beginning/newly transferred teachers in Ondo State Nigeria is high. On this point also, if the first finding is logically followed: that orientation programme was considered important, then, it ought to be given required efforts to ensure effectiveness. Notwithstanding, this finding is valid, more in general form. Observation of Table $1 \mathrm{~b}$ shows that this finding is the result of fifteen items ( 3 to 17) and six of them namely, items 3 (53.85\%), 8 (46.15), 9 (53.85\%), 10 
(53.85\%), $12(46.15 \%)$, and $13(53.85 \%)$, did not show high enough scores while two are particularly weak (items 8 and 12: $46.15 \%$ each). Consequently, more efforts are required in four items on need for beginning/newly teachers to share their problems/concerns openly (item 3), beginning teachers should not be assigned to students that had been rejected by experienced teachers (item 9) or facilities that are regarded as less desirable by experienced teachers (item 10), and new teachers should be allowed to participate in the selection of curricular materials that they would use in their classes (item 13), co-construction. One of the two weakest findings suggest that beginning teachers were assigned to courses that were rejected by experienced teachers (item 8): that is unfair/undemocratic. [20] noted that equality should be stressed because situations of advantaged and disadvantaged people merely portray class distinctions which tend to divide people and disunite society; several more recent writers including [2], [3], [4], [6], and [7] agree. The other weakest finding indicates that assistance sought by new teachers was not readily provided by the school (item 12). This issue may affect heads of department, principals, community, and even government. Facilities and services required by new teachers as [2] put it, such as, classroom management, instruction, curriculum, school culture and operations, test preparation and administration, government standards, parent-teacher relations, and teacher- teacher relations, should be provided as readily as possible to motivate new teachers such that they make the profession their life-time career.

Magnitude of involvement of all beginning/newly transferred teachers by Principals in the whole programmes of their schools in Ondo State Nigeria is high, is the last finding and it supports situation found in literature on professional development [9], [1], [2], [10], [6] and [7]. It follows that Principals in Ondo State Nigeria secondary schools were quite conscious of their role as heads of secondary schools and the need for them to involve all new teachers.

As suggested by [15], the number of specific areas which show weaknesses or inadequacies in the orientation for beginning/newly transferred teachers in Ondo State Nigeria give a clearer picture than the general one in the first empirical research. This then, is a major benefit of conducting research on definite (focused) problems. Consequently, more of such empirical researches would be valuable.

\section{Conclusion}

Findings from this research have portrayed that effectiveness degree on orientation for beginning /newly transferred teachers in Ondo State Nigeria is generally high. Notwithstanding, a number of specific areas require improvement.

\section{Recommendations}

The following recommendations are obvious from the findings of this research.

- Principals should supervise assigning of courses such that heads of department are discouraged from assigning courses that are rejected by experienced teachers to new teachers.

- All leaders including supervisors, principals, heads of department, and other experienced teachers, should cooperate and provide assistance needed by new teachers as readily as possible, to encourage new teachers.

- Beginning/newly transferred teachers should be allowed sufficient freedom such that they can confidently share their problems/concerns openly.

- Beginning teachers should not be assigned to students that had been rejected by experienced teachers.

- Beginning teachers should not be assigned to facilities that are regarded as less desirable by experienced teachers.

- New teachers should be allowed to participate in the selection of curricular materials that they would use in their classes.

- More of such focused empirical research as this, are required on the stage of professional development in Ondo State Nigeria, for clearer picture, for obvious ultimate benefit for schools and society.

\section{References}

[1] Tanner, D. and Tanner, L. N. (2007) Curriculum Development: Theory into Practice (Fourth ed.), Pearson Education Inc., New York.

[2] Mizell, H. (2010) 'Why professional development matters', Learning Forward, Oxford. Retrieved from Learningforward.org.drcs/pdf.why-pd-matters-web. pdf?sfvrsn $=0$.

[3] Timperly, H. S. (2011) Realizing the power of Professional Learning, Open University Press, England and New York.

[4] Skinner, D. (2013) Effective Teaching and Learning in Practice, Bloomsbury Academy, New York. 
[5] Loughran, J. (2014) 'Professionally developing as a teacher educator', Journal of Teacher Education, 65(4), pp. 271-283, doi: 10-11771002248714533386.

[6] Hardman, F., Hardman, J., Dachi, H., Elliot, L., Ihebuzor, N., Ntekim, M., and Tibuhinda, A. (2015) 'Implementing school-based teacher development in Tanzania', Professional Development in Education, 41(4), p. 602-623. DOI: $10.1080 / 19415257.201-$ 5026453.

[7] Israel, M. (2015) 'Teachers observing teachers: a professional tool for every school', Education World. Retrieved from: www.educationworld.com/aadmin/admin/admin297.shtml.

[8] Education World (2015) 'Staff development through peer mentoring'. Retrieved from: www.educationworld.com/a-admin/teachertraining/ teacher-training006.shtml.

[9] Sparks, D. and Loucks-Horsley, S. (2007) 'Five models of staff development for teachers', in Ornstein, A. C., Pajak, E. F., and Ornstein, S. B., Contemporary Issues in Curriculum (Fourth ed.), Pearson Education Inc., p.303-326.

[10] Nagel, D. (2013) 'Reports: Effective teacher professional development crucial to common core', Education for 1105 Media Inc. Retrieved from: www.thejournal.com/articles/2013/09/10/report-effective-teacher-professional-development-crucial-tocommon-core-aspx.

[11] Desimone, L. M. (2009) 'Improving impact studies of teachers' professional development: Toward better conceptualizations and measures', Education Research, 38(3), pp. 181-199. DOI: 10.3102/0013189 X08331140.

[12] Fishman, B., Konstantopoulos, S., Kubitskey, B. W., Vath, R., Park, G., Johnson, H., Edelson, D. C. (2013) 'Comparing the impact of online and face to face professional development in the context of curriculum implementation', Journal of Teacher Education, 64(5), pp. 426-438.Doi: 10-11771002248 7113494413 .

[13] Kisa, Z. and Correnti, R. (2014) 'Examining implementation fidelity in America's choice schools: a longitudinal analysis of changes in the professional development associated with changes in teacher practice', Educational Evaluation and Policy Analysis. doi: $\quad 10.3102 / 0162373714557519 ; \quad$ doi: 0162373714557519 .
[14] Bergh, L., Ros, A., and Beijaard, D. (2014) 'Improving teacher feedback during active learning: Effects of a professional development program', American Educational Research Journal, 51(4), pp.772-809. doi: 10.3102/0002831214531322.

[15] Kukuru, J. D. (2015a) 'Stage of professional development toward reforming secondary schools in Ondo State Nigeria', in Proceedings of World Congress on Special Needs Education (WCSNE2015), Infonomics Society, p. 208-216.

[16] Iyunade, O. T. (2011) 'Teachers' continuing professional development as correlates of sustainable universal basic education in Bayelsa State, Nigeria', African Research Review, 5(4), pp. 161-177. Retrieved from http:www.ayol.info/index.php/Afrrev/ viewFile/69274/57303.

[17] Oluremi, O. F. (2013) 'Enhancing educational effectiveness in Nigeria through teachers' professional development, European Scientific Journal, 9(28), pp. 422-431.Retrieved from eu.journal.org/files/ journal/1/articles/1907/public/1907-5688-/-PB.pdf.

[18] Ememe, P. I., Aitokhuehi, O. O., Jegede, S., and Ojo-Ajibare, J. O. (2013) 'Enhancing teaching quality through continuing professional education', European Journal of Education Studies, 5(2), pp. 277-291. Retrieved from: oze/academy.com/ejes.v5.12-7.pdf.

[19] Cohen, L., Manion, L., and Morrison, K. (2011) Research Methods in Education (Eight ed.), The McGraw Hill Companies Inc., New York.

[20] Ornstein, A. C. (2007) Education, equality, and equity, in Ornstein, A. C., Pajak, E. F., and Ornstein, S. B. (Eds.), Contemporary Issues in Curriculum (Fourth ed.), Pearson Education Inc. p. 428-443. 